\title{
A study on the effect of knowledge management on job satisfaction: A case study of texture industry
}

\author{
Rahmatollah Jadidi $^{\mathrm{a}}$, Mohammad Ehsanifar ${ }^{\mathrm{b}}$ and Sahar Moshtaghi $^{\mathrm{c}^{*}}$,
}

${ }^{a}$ Department of development center, Arak University of Medical Sciences, Arak, Iran

${ }^{b}$ Department of Management, Islamic Azad University, Tafresh Branch, Tafresh, Iran

${ }^{c}$ Department of Management, Islamic Azad University, Arak Branch, Arak, Iran

\section{H R O N I C L E \\ A B S T R A C T}

Article history:

Received May 12, 2013

Received in revised format

12 September 2013

Accepted 6 October 2013

Available online

October 162013

Keywords:

Knowledge management

Job satisfaction

Texture industry

\begin{abstract}
This paper presents an empirical investigation to study the effect of knowledge management on job satisfaction in Iranian texture industry. The proposed study of this paper designs a questionnaire and distributes it among 219 out 230 employees who work for one Iranian texture firm in province of Markazi in Iran. The study uses structural equation modeling to examine different hypotheses based on the implementation of LISREL software package. The results of our investigation indicate that knowledge management positively influences on organizational improvement, organizational learning as well as quality improvement. The results of study also indicate that while there was a negative relationship between organizational improvement and job satisfaction, quality improvement and organizational learning positively influence on job satisfaction.
\end{abstract}

\section{Introduction}

Knowledge plays essential role on managing today's organizations and it helps managers make essential decisions (Seevers, 2000). Knowledge management is considered as the key success for making continuous improvement on business units and a successful organization normally maintains more satisfied employees (Polyani, 1966). Therefore, it is important to learn more about the relationship between knowledge management and job satisfaction. Design management and process management are two essential components of total quality management (TQM) implementation. They are practically different in their objectives of improvement, visibility, and techniques. Ahire and Dreyfus (2000) built a framework for detecting the synergistic linkages of design and process management to the operational quality outcomes during the manufacturing process and upon the field usage of the products. They performed a detailed contingency analysis and reported that their 
proposed model of synergies between design and process management hold true for large and small firms. They also suggested that organizational learning enables mature TQM firms to apply both design and process efforts more rigorously and their synergy assists these firms to gain better quality outcomes. Abou-Zeid (2002) developed a three-layer, cognitive domains, functional and resources, reference model for knowledge management systems. The primary objective of this model is to identify the processes to be supported by any knowledge management support system (KMSS), for modeling the dynamics of these processes. It also helps to develop a framework of a business-aware model to KMSS development methodology, and to develop blueprints for information/communication technology (ICT)-based KMSS. Alavi and Leidner (2001) presented a comprehensive review of knowledge management literatures in various fields with an eye toward detecting the important areas for research. They presented a detailed process view of organizational knowledge management by looking into on the potential role of information technology in this process.

Javanmard and Alhosseini (2013) performed an empirical investigation to detect important factors affecting expediting knowledge distribution in one of Iranian firms. They designed a questionnaire and distributed it among a randomly selected employees and using some statistical test, the relationship between knowledge distribution as dependent variables with eight independent variables are investigated. They reported that informal mechanism, building a good trust within organization, having a good interaction among various units of organization, hiring highly committed employees, improving innovation, and learning capabilities within organization may help expedite distribution of knowledge within organization. However, the survey did not find any statistical evidence to believe that formal mechanism, having a good identity and stating objective had any meaningful impact on distributing knowledge within organization.

Emami et al. (2013) presented an empirical investigation to investigate the relationship between knowledge management and organizational change in one of Iranian producers of wire and cable. The results of Spearman correlation coefficients in their study showed that harvest index, refining, organizing, disseminating and applying knowledge had positive and meaningful relationship with organizational change. They concluded that managers have to develop organizational change to integrate the wealth of knowledge in various sectors and having knowledge of internal and external forces.

\section{The proposed study}

This paper presents an empirical investigation to study the effect of knowledge management on job satisfaction in texture industry. The proposed study of this paper designs a questionnaire adopted from Allameh and Zare (2011) and distributes it among 219 out 230 employees who work for one Iranian texture firm in province of Markazi in Iran. There are six hypotheses with the proposed study of this paper as follows,

1. Knowledge management positively influences on organizational development.

2. Knowledge management positively influences on organizational learning.

3. Knowledge management positively influences on quality improvement.

4. Organizational development positively influences on job satisfaction.

5. Organizational development positively influences on job satisfaction.

6. Quality improvement positively influences on job satisfaction. 
Fig. 1 demonstrates the proposed study of this paper.

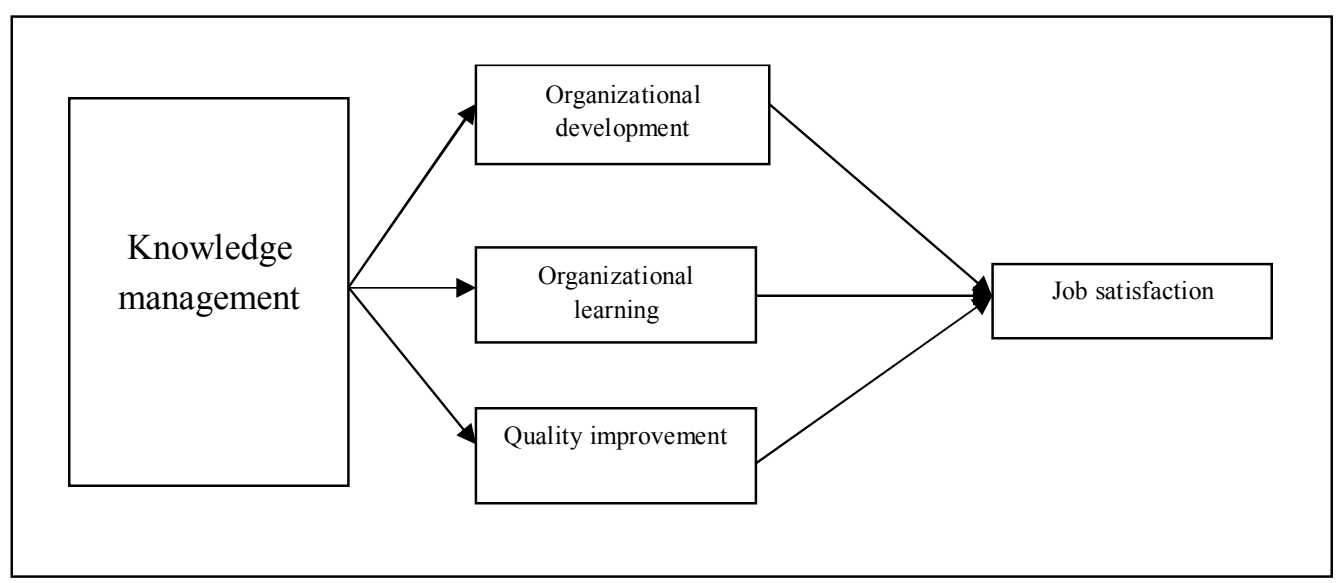

Fig. 1. The proposed study

Table 1 shows the results of Cronbach alpha for different components of the survey.

Table 1

The summary of Cronbach alpha

\begin{tabular}{lccc}
\hline Perspective & \# of questions & Questions & Cronbach alpha \\
\hline Knowledge management & 14 & $1-14$ & 0.861 \\
Organizational development & 4 & $15-18$ & 0.772 \\
Organizational learning & 12 & $19-30$ & 0.875 \\
Quality improvement & 4 & $31-34$ & 0.787 \\
Job satisfaction & 4 & $35-38$ & 0.942 \\
\hline Total & & & 0.954 \\
\hline
\end{tabular}

As we can observe from the results of Table 1, the Cronach alphas for all components of the survey are well above the minimum acceptable level.

\section{The results}

In this section, we present details of our findings on testing various hypotheses of the survey.

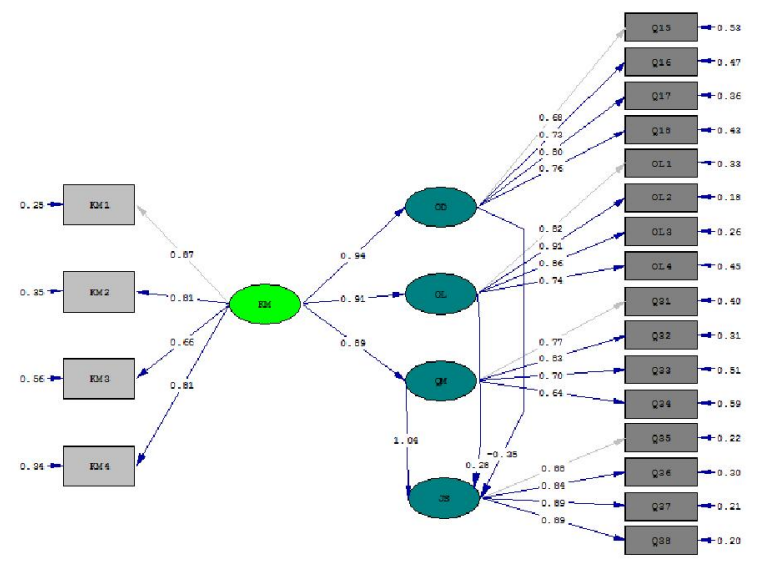

Chi-Square $=479.49$, df $=164$, P-value $=0.00000$, RMSEA $=0.094$

Standard values

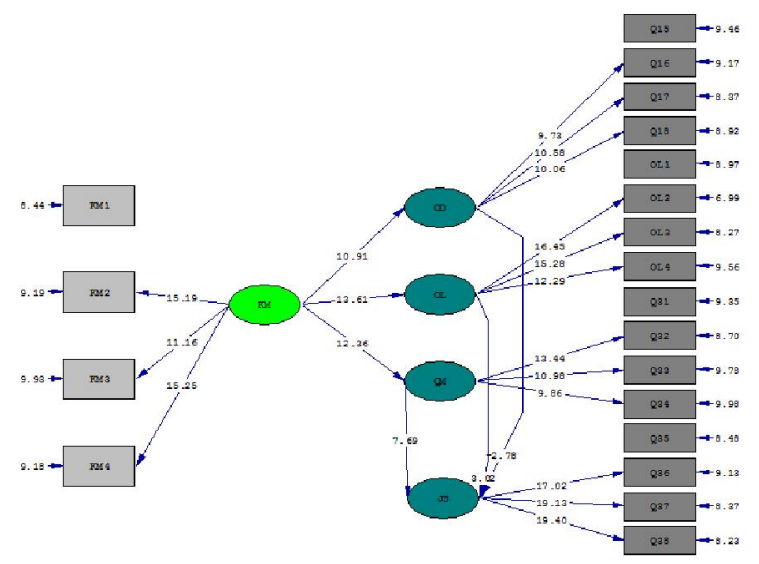

Chi-square $=479.49$, df $=164$, P-value $=0.00000$, EMMSE $A=0.094$

t-student values 
Fig. 2. The results of structural equation modeling

Table 2 summarizes the results of our investigation.

Table 2

The summary of the results of structural equation modeling

\begin{tabular}{|c|c|c|c|}
\hline Variable & Parameter & Standard coefficient & t-student \\
\hline \multirow{4}{*}{$\begin{array}{l}\text { Knowledge management } \\
(\mathrm{KM})\end{array}$} & KM1 & 0.87 & ------- \\
\hline & KM2 & 0.81 & 15.19 \\
\hline & KM3 & 0.66 & 11.16 \\
\hline & KM4 & 0.81 & 15.25 \\
\hline \multirow{4}{*}{$\begin{array}{l}\text { Organizational development } \\
\text { (OD) }\end{array}$} & Q15 & 0.68 & ------- \\
\hline & Q16 & 0.73 & 9.73 \\
\hline & Q17 & 0.8 & 10.58 \\
\hline & Q18 & 0.76 & 10.06 \\
\hline \multirow{4}{*}{$\begin{array}{l}\text { Organizational learning } \\
(\mathrm{OL})\end{array}$} & OL1 & 0.82 & ------- \\
\hline & OL2 & 0.91 & 16.45 \\
\hline & OL3 & 0.86 & 15.28 \\
\hline & OL4 & -0.74 & 12.29 \\
\hline \multirow{4}{*}{$\begin{array}{l}\text { Quality management } \\
(\mathrm{QM})\end{array}$} & Q31 & 0.77 & ------- \\
\hline & Q32 & 0.83 & 13.44 \\
\hline & Q33 & 0.7 & 10.98 \\
\hline & Q34 & 0.64 & 9.86 \\
\hline \multirow{4}{*}{$\begin{array}{c}\text { Job satisfaction } \\
\text { (JS) }\end{array}$} & Q35 & 0.88 & ------- \\
\hline & Q36 & 0.84 & 17.02 \\
\hline & Q37 & 0.89 & 19.13 \\
\hline & Q38 & 0.89 & 19.4 \\
\hline
\end{tabular}

The results of t-student values shown in Table 2 are statistically significant with $\alpha=5 \%$. Now we can verify six hypotheses of the survey.

\subsection{The first hypothesis: The relationship between KM and OD}

The first hypothesis of this survey tries to find out whether or not knowledge management positively influences on organizational development. Table 3 shows details of our findings as follows,

Table 3

The result of testing the first hypothesis

\begin{tabular}{ccccc}
\hline Hypothesis & Path & $\beta$ & t-student & Result \\
\hline First & KM $\rightarrow$ OD & 0.94 & $10.91>1.96$ & confirmed \\
\hline
\end{tabular}

The results of Table 3 indicate that knowledge management positively influences organization development when the level of significance is five percent.

\subsection{The second hypothesis: The relationship between $K M$ and $O L$}

The first hypothesis of this survey tries to find out whether or not knowledge management positively influences on organizational learning. Table 4 shows details of our findings as follows,

\section{Table 4}

The result of testing the second hypothesis

\begin{tabular}{ccccc} 
Hypothesis & Path & $\beta$ & t-student & Result \\
Second & $\mathrm{KM} \rightarrow \mathrm{OL}$ & 0.91 & $13.61>1.96$ & confirmed \\
\hline
\end{tabular}


The results of Table 4 indicate that knowledge management positively influences organization learning when the level of significance is five percent.

\subsection{The third hypothesis: The relationship between KM and QM}

The third hypothesis of this survey tries to find out whether or not knowledge management positively influences on quality management. Table 5 shows details of our findings as follows,

Table 5

The result of testing the third hypothesis

\begin{tabular}{ccccc}
\hline Hypothesis & Path & $\beta$ & t-student & Result \\
\hline Third & $\mathrm{KM} \rightarrow \mathrm{QM}$ & 0.89 & $12.36>1.96$ & confirmed \\
\hline
\end{tabular}

The results of Table 5 indicate that knowledge management positively influences quality management when the level of significance is five percent.

\subsection{The fourth hypothesis: The relationship between $O D$ and JS}

The fourth hypothesis of this survey tries to find out whether or not organizational development positively influences on job satisfaction. Table 6 shows details of our findings as follows,

Table 6

The result of testing the fourth hypothesis

\begin{tabular}{ccccc} 
Hypothesis & Path & $\beta$ & t-student & Result \\
\hline Fourth & OD $\rightarrow$ JS & -0.35 & $|-2.78|>1.96$ & confirmed \\
\hline
\end{tabular}

The results of Table 6 indicate that organizational development negatively influences job satisfaction when the level of significance is five percent.

\subsection{The fifth hypothesis: The relationship between OL and JS}

The fifth hypothesis of this survey tries to find out whether or not organizational learning positively influences on job satisfaction. Table 7 shows details of our findings as follows,

Table 7

The result of testing the fifth hypothesis

\begin{tabular}{ccccc}
\hline Hypothesis & Path & $\beta$ & t-student & Result \\
\hline Fifth & OL $\rightarrow$ JS & 0.28 & $3.02>1.96$ & confirmed
\end{tabular}

The results of Table 7 indicate that organizational learning positively influences job satisfaction when the level of significance is five percent.

\subsection{The fifth hypothesis: The relationship between QM and JS}

The last hypothesis of this survey tries to find out whether or not quality management positively influences on job satisfaction. Table 8 shows details of our findings as follows,

Table 8

The result of testing the sixth hypothesis

\begin{tabular}{ccccc}
\hline Hypothesis & Path & $\beta$ & t-student & Result \\
\hline Sixth & QM $\rightarrow$ JS & 1.04 & $7.69>1.96$ & confirmed \\
\hline
\end{tabular}


The results of Table 8 indicate that quality management positively influences job satisfaction when the level of significance is five percent.

\section{Conclusion}

In this paper, we have presented an empirical investigation to find the effect of knowledge management on job satisfaction. The study has been applied in one of Iranian texture industry and the results have confirmed that knowledge management positively influenced organizational development, organizational learning and quality management. In addition, quality management as well as organizational learning influence on job satisfaction but organizational development negatively influences on job satisfaction.

\section{Acknowledgement}

The authors would like to thank anonymous referees for constructive comments on earlier version of this paper.

\section{References}

Abou-Zeid, E. S. (2002). A knowledge management reference model. Journal of Knowledge Management, 6(5), 486-499.

Ahire, S. L., \& Dreyfus, P. (2000). The impact of design management and process management on quality: an empirical investigation. Journal of Operations Management, 18(5), 549-575.

Alavi, M., \& Leidner, D. E. (2001). Review: Knowledge management and knowledge management systems: Conceptual foundations and research issues. MIS quarterly, 25(1), 107-136.

Allameh, S. M., \& Zare, S. M. (2011). Examining the impact of KM enablers on knowledge management processes. Procedia Computer Science, 3, 1211-1223.

Emami, M., Feridouni, H., Kia, S.H., \& Monnavari, M.S. (2013). A study on relationship between knowledge management and organizational change in learning organizations: A case study of cable industry. Management Science Letters, 3(10), 2651-2664.

Javanmard, H., \& Alhosseini, Z.S. (2013). A study on effect of social capital on expediting knowledge distribution. Management Science Letters, 3(10),2665-2668.

Polyani, M. (1966). Personal Knowledge: Towards a Post-Critical Philosophy, University of Chicago Press, Chicago, IL.

Seevers, B. S. (2000). Identifying and clarifying organizational values. Journal of Agricultural Education, 41(3), 70-79. 